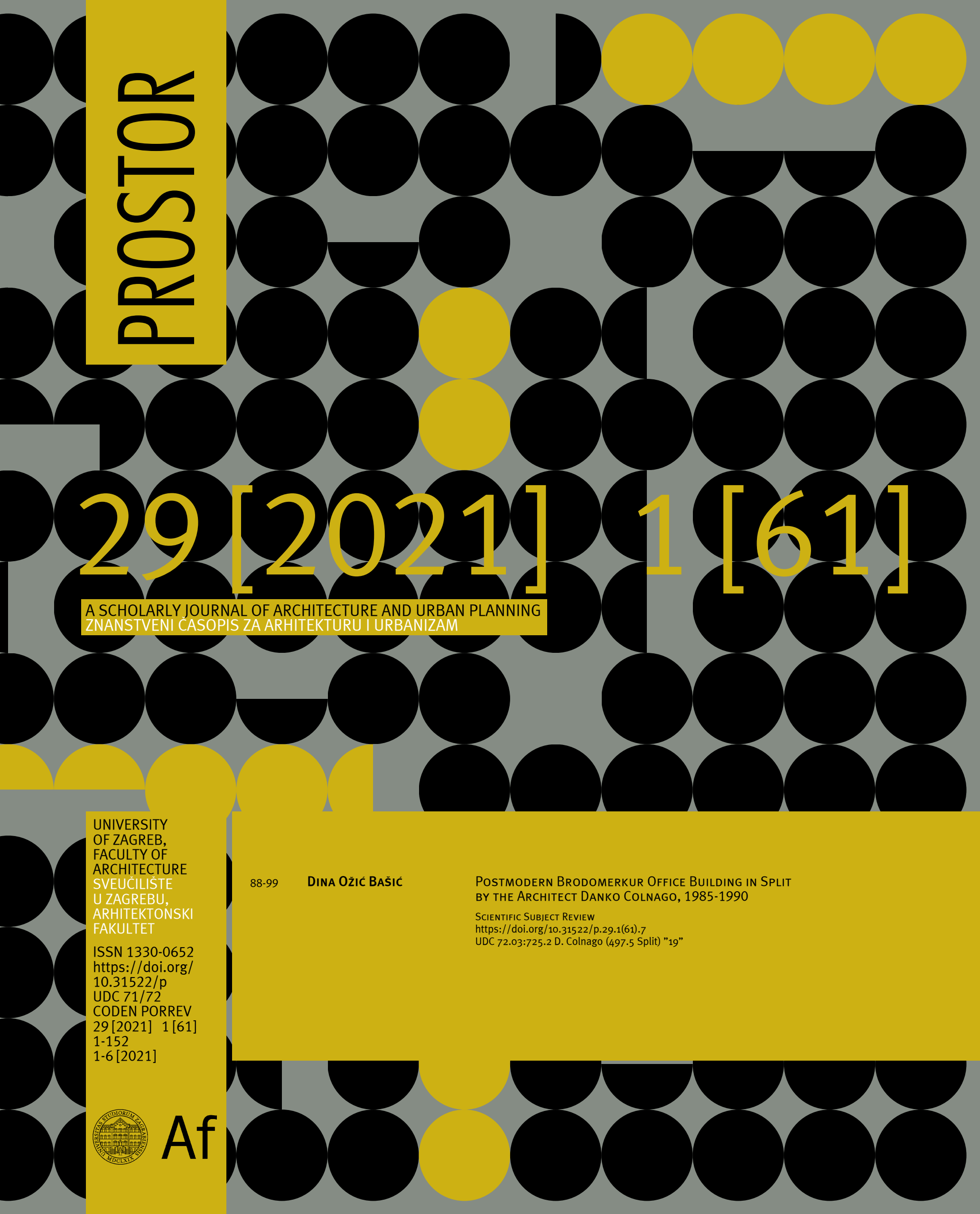




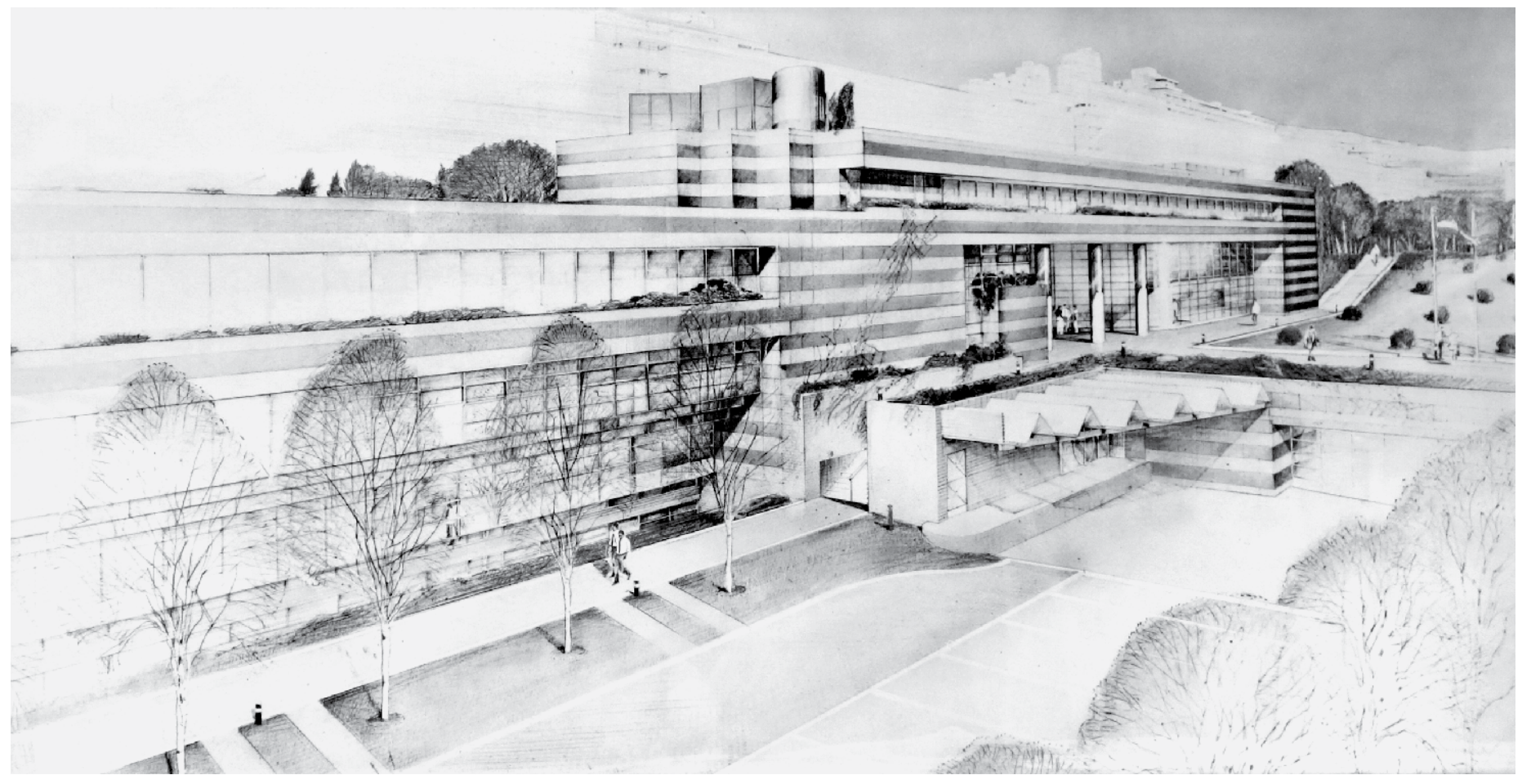

Fig. 1 Perspective drawing of the Office Building of the Brodomerkur Company, author Branka Kaminski 
DINA OŽıĆ BAŠıĆ

Office of licenced Architect Dina Ożıć Bašic (Ured ovlaštene arhitektice), Sts Cyril and Methodius Street 38, Split, Croatia dob2112@yahoo.com

SCIentific Subject ReVIew

https://doi.org/10.31522/p.29.1(61).7

UDC 72.03:725.2 D. Colnago (497.5 SPLIT) "19"

Technical SCIEnces / Architecture and URban Planning

2.01.04. - History and Theory of Architecture and Preservation of the Built Heritage

Article Received / Accepted: 17. 3. 2021. / 18. 6. 2021.

\title{
Postmodern Brodomerkur Office Building in Split By the ARChItect DANKo Colnago, 1985-1990
}

\author{
BRodomerkUR OfFICE BUILDING \\ Colnago, DANKo \\ OFFICE BUILDING \\ POSTMODERN ARCHITECTURE \\ SPLIT, CROATIA
}

This paper is a contribution to the knowledge about the 1980s postmodern architecture in the city of Split. It is focused on the Brodomerkur Office Building as an outstanding example of postmodern office space at the urban heart of Split. The study analyses the building's urban and architectural features, which are evaluated in both the local and global context. Brodomerkur's unique design makes it an architectural gem worthy of landmark status and preservation. 


\section{INTRODUCTION}

A units in the city's quarter of Smrdečac from the 1970 s to the 1980 - within the Basic Urban Design Project for Split III - construction of commercial and office buildings began in the remaining area of the urban matrix. The goal was to provide jobs for the local population, not only in the industrial zones around the city but also near its residential areas. The offices building of the Brodomerkur Company (today the Faculty of Humanities and Social Sciences, University of Split) is located among commercial and office buildings in Smrdečac. This article examines postmodern architectural features of an office building in a paradoxical situation. It is a building that resembles lavish headquarters of a large, capitalist multinational corporation when in fact it was conceived and built in what was at the time a socialist country. Compared to other buildings in the city's urban landscape, Brodomerkur stands out as an example of architectural creativity of the 1980s. Its presence in the memory of Split, with its numerous architectural associations, demands this building's preservation as a shining exemplar of the city's rich architectural heritage.

\section{URBAN CONTEXT}

After World War II, municipal planners of the small City of Split plotted its development through post-war production of social hous- ing. During the industrialisation period between 1961 and 1971, the city's population doubled in size from 78792 to 163762 inhabitants. As the population grew, so did the demand for housing, transportation, and communal solutions. Subsequent scientific and professional studies resulted in the Conception of the General Urban Plan of the City of Split, adopted on April 15, 1974 (Kalogjera, 1977: 1, 7, 9, 11; Fig. 3). ${ }^{1}$

The polycentric scheme of city organisation on the Split peninsula showed the modernist division of zones: dwelling, recreation, work, and transportation. However, black squares mark four city centres as the Lynch's urban nodes with a concentration of public content (Lynch, 1960: 72-78): Split (west), Solin (north), Stobrec (east), as well as a new planned city centre in the central part of the Split peninsula.

The new city centre was planned for 50210 inhabitants and $30500 \mathrm{~m} 2$ intended for trade, service, catering, and business functions (Kalogjera, 1977: 14-16, 41-42). It was divided and organised "along two heliothermal axes, northwest-southwest direction, and in parallel to the map of cardo of Diocletian's palace" (Tušek, 1996: 188; Kukoč, 2010: 171). ${ }^{2}$ The western axis forms a postmodern pedestrian "University Street" in the city quarter Smrdečac, which was planned south and north of Poljička Street (Kalogjera, 1977: 42; Fig. 3).

The part of the city centre at Smrdečac, located along the traffic corridor of Poljička Street

1 Work on the GUP of the City of Split began with the Decision of the Municipal Assembly of Split (Skupstina opcine Split) on November 16, 1967; Book 1: Documentation was published in 1971; Book 2: Conception was published in 1972, Book 3: Plan proposal was published in 1977 and the Plan was finally authorized in 1978. The Conception assumed population growth - 324000 inhabitants up to the year 2000 .

2 The idea of the city centre grew out from different documents: the winning Competition Entry Žnjan from Slovenian team from Ljubljana (Vladimir Mušič, Marjan Bežan, and Nives Starc, Urban Institute of Slovenia, 1968/1969), the Action Plan for the development of Split III, second phase of development preparations (Company for the Construction of the City of Split / Poduzece za izgradnju Splita, April 1969) and the Basic Urban Design Project for the City of Split III (Marjan Beżan, with the collaboration of the Slovenian Urban Planning Institute from Ljubljana and Urban Planning Institute of Dalmatia / Urbanisticki zavod Dalmacije from City of Split, December 1969).

3 Poljicka Street and the so-called Solinska Street once connected Aspálathos / Spalatum (today Split) with Epidaurum / Raúsion (today Stobrec) and Salona (today Solin), respectively. These were two main city streets for 17 centuries.

4 Danko Colnago (1952) graduated from the Faculty of Architecture, the University of Zagreb in 1976. He started working in the Construction Company Ivan Lučic Lavčevic in 1977. Later he was the owner of the architectural bureau CD project d.o.o. founded in 1990. In more recent years, he designed yachts and speedboats in the company Pakleni otoci d.o.o. Today he is retired. 
(one of the two main city roads; Fig. 3$)^{3}$, had remained undeveloped for a long time. The plan for the construction of one of several planned commercial buildings on this stretch of road was implemented in the mid-1980s. The existing postmodern urban pattern of "pedestrian streets" in the residential area of the city quarter of Smrdecac is set in the east-west direction, in parallel to the Poljička Street (the street is partly situated on the Roman limitatio; Suic, 1956: 13), and is connected to the central pedestrian street that links the University Campus with the business district (Ruđer Boškovic Street). This position determined the plot for construction and, consequently, the longitudinal layout of the Brodomerkur building (Figs. 3 and 4).

\section{DESIGN AND CONSTRUCTION}

The author of the project, architect Danko Colnago ${ }^{4}$, made the preliminary design for Brodomerkur for 500 employees in 1985 , as one of the licensed architects at the company Ivan Lučic Lavčevic - OOUR Design and Technology Bureau (Ivan Lučić Lavčević - OOUR Projektno tehnološki biro). Associate architect Branka Kaminski (1956- 2002) presented Colnago's design through a hand-drawn perspective (Figs. 1 and 2).

Terms for the building were issued by the Committee on Urbanism, Construction, Property Law, Housing and Communal Affairs, Directorate for Urbanism and Construction, De-

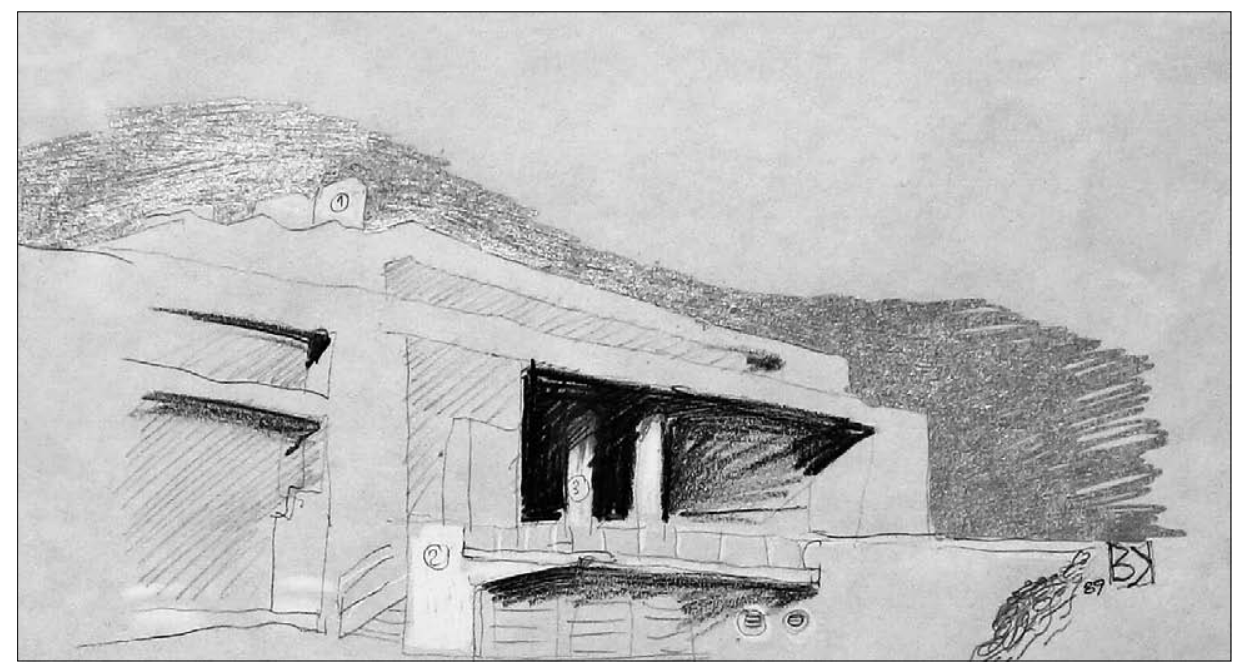

partment for Terms of Construction (Komitet za urbanizam, gradevinarstvo, imovinsko pravne, stambene i komunalne poslove, Uprave za urbanizam i gradevinarstvo, Odsjek za uvjete građenja građevina) on April 7, 1986 , for a building plot of $2700 \mathrm{~m} 2$ (cadastral parcels 1332/1 and 1336/1, Cadastral municipality Split; Danko Colnago Archive). They prescribe the building construction coefficient of 1 and a $6 \mathrm{~m}$ wide pedestrian passage through the building. The building permit was issued on May 25 and the amended building permit, with a reduction of the basement floor area, was issued on November 2, 1989 (the City of Split Archives). The supple-
Fig. 2 Perspective drawing of the Brodomerkur OFFICE BUILDING, AUTHOR BRANKA KAMINSKI
Fig. 3 Scheme of SPlit ANd the New City Centre OF SPLIT III (GUP, 1977)

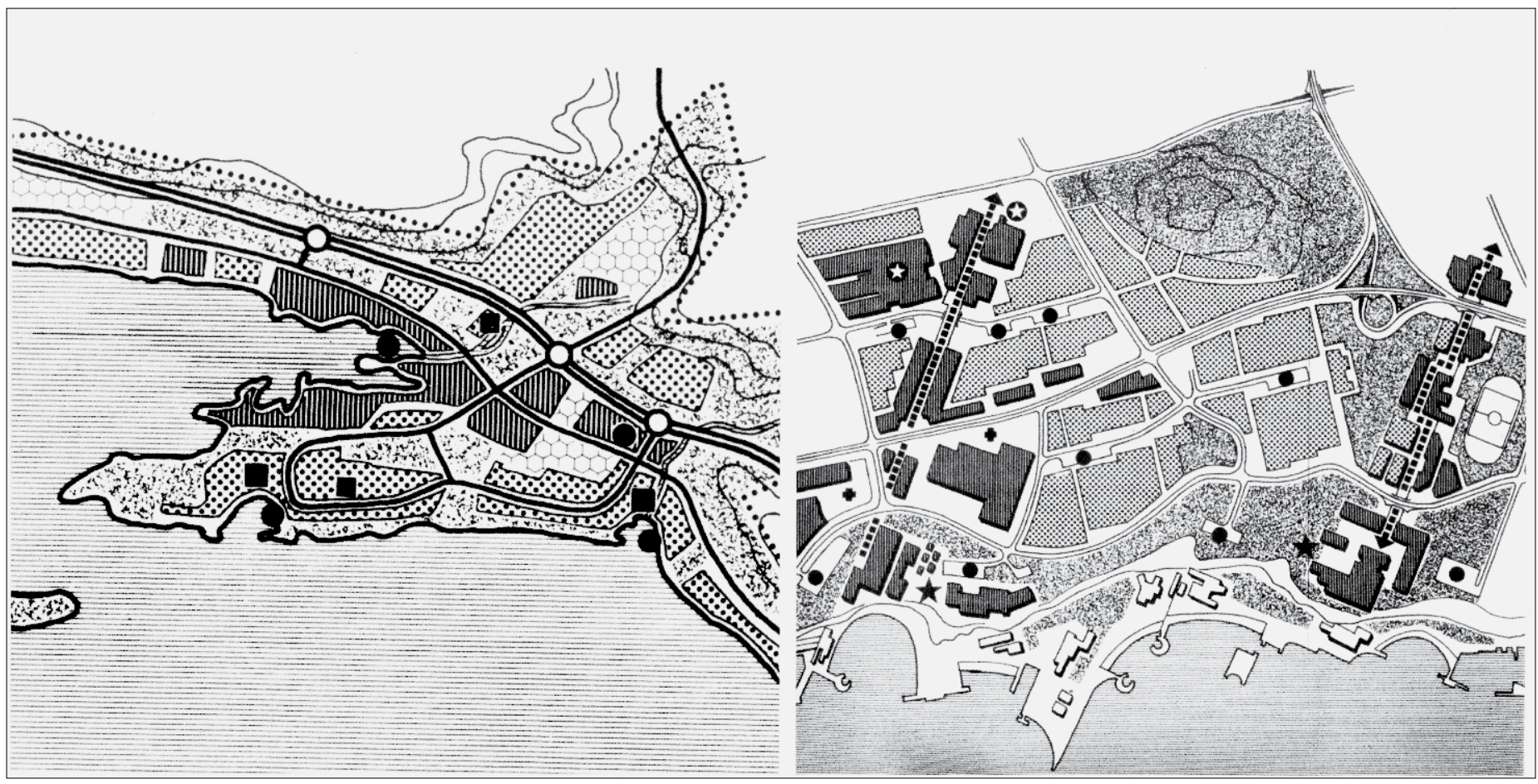




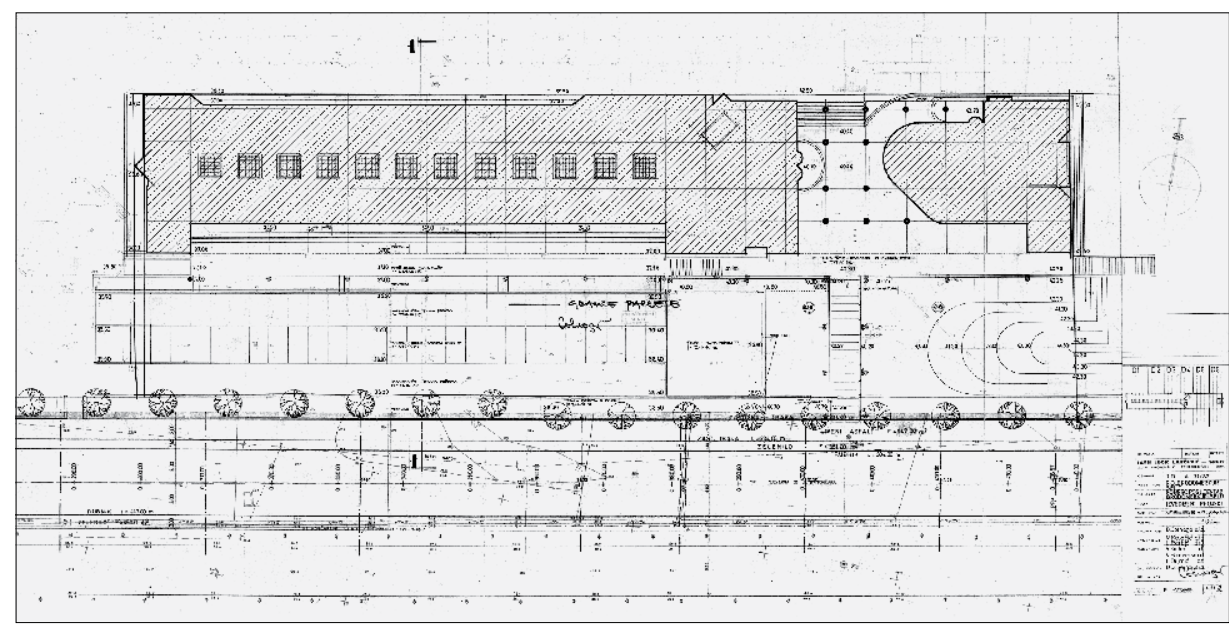

Fig. 4 Site plan of the Brodomerkur OfFice Building, AUTHOR DANKO COLNAGO

ment to the building permit, with the project documentation for the elevators, was issued on June 5, 1990 (the City of Split Archives).

Preparations for the construction of the building lasted four years. This amount of time was needed not only for the design process but also for the purchase and consolidation of land (consolidating many smaller plots into one big plot) and the complete arrangement of the building plot, which was carried out for the Brodomerkur Labour Organization (Radna organizacija Brodomerkur) by the Company for the Construction of the City of Split (Poduzece za izgradnju Splita). The construction site opened in 1988. During the construction of the building, in the period from 1989 to 1990 , architect Colnago was "moved" from the design office to the construction site.

\section{URBAN AND ARCHITECTURAL FEATURES}

In the search for a different and more personal physical reality of the new spatial sign in relation to the external environment, the long and narrow belt of the building plot conditioned the concept of placing a "limes" - the volume of a building that appears as a "wall" defending the housing district from the Lynch's "edge" - strong six-lane road (Lynch, 1960: 62-66). The thickness of the "wall" is ambiguous, emphasizing at the same time the separation of the residential district from the main road and the separation of the inner space of the building from the outer (Figs. 5 and 6).

The "wall" is open lengthwise with two large openings, forming two "portals". The opening of the "wall" is ambiguous: it opens the inner space to the outside ("positive"), achieving either visual communication at breakthrough points or the opening of the passage through the house ("negative"; Giedion, 1969: 31-33). The sidewalls of the house are closed, for protection ("shelter") and for constructive demands.

The volume of the western "portal" is set lower than the eastern, due to the difference in the height of the natural terrain on the eastern and western part of the Brodomerkur building, and due to the requirement for the pedestrian access to the building from the slope of nearby Poljička Street (the ground floor of the eastern part of the building is the first floor of the western part of the building). ${ }^{5}$ In addition to this difference in the terrain's / building's altitude, the partial burial of the northern façade for1.2 $\mathrm{m}$ down contributes to the experience of a lower volume seen from the $5 \mathrm{~m}$ wide pedestrian street separating the building from the front gardens of residential buildings (Fig. 6).

The eastern and western "portals" are both connected by a floor slab, which serves as a flat roof for the western side and the last floor for the eastern side. These portals close the "bridge construction" of the building, resting on "pillars" of the three reinforced concrete cores consisting of the staircases and toilets blocks, located along the east and west façades and in the middle of the building. The "bridge construction" enabled a significant opening of the façade by glazing, so the strength of the two prominent reinforced concrete "portals" alternates with the cascading retraction (southwest; Fig. 7) and/or a soft curve (southeast; Figs. 5 and 6) made of glass as the "curtain wall". Cascades form strokes/strips, which together with the pregnant volume of the "bridge/portal", serve to create a deep shadow that protects the windows and reduces the intensity of strong Mediterranean sunlight during the summer. The soft curve gently pulls towards the interior of the building, emphasizing the location of the pedestrian entrance and protecting the windows from the low western sun.

The glazed cascades at the southern façade of the western part of the building are paved with 48 horizontally placed glass panels, 10 rows high, where the two central rows are pulled towards the interior of the building forming a "cornice" at the mezzanine structure. The "cornice" also appears along the northern glass façade of the western part of the building (Fig. 6). The main vertical division of the glass façade into three parts arises from the functional requirement for two

$5 \quad$ Cascading fence wall, which follows the slopes of the naturally hilly terrain with the rhythm of horizontal jumps, is common in Split: along Vukovarska Street, on the Marjan Stairs, as well as on building plots from the $19^{\text {th }}$ and the $20^{\text {th }}$ century.

6 Due to the "typological determinants in the organisation of space (central covered atrium space and gallery)" Plejic claims that the building is "close" to the atrium 
dilatations, while the denser vertical division of the façade arises from the modular division of the floor plan, which allows variable layouts for the office in the interior. By using surfaces made of grey-blue tinted thermoglass (platinum oxide produces a blue-grey tone), the building adapts to the weather conditions, the existing urban matrix, and the internal functions.

The building retains tectonics - a classic feature of durability (Vitruvius, 1990: 18) and a feature of power through size and weight (Ruskin, 1920: 72, 75, 77-78, 102) and, despite the postmodern "masking" of the main structure by stone cladding, it clearly shows the totality of its reinforced concrete structural origin. The alternating use of strips with the polished cladding of black granite from a site in Jablanica and White Dolit - beige limestone from the island Brač (stone slabs measuring $60 \times 40 \mathrm{~cm}$ ) - on the surface of the façade, emphasizes the importance of the material and gives the wall texture, simultaneously accentuates the force of the total mass (Ruskin, 1920: 80, 88 89).

The building is $141.05 \mathrm{~m}$ long and $24.235 \mathrm{~m}$ wide and ultimately covers the building plot of $3,450 \mathrm{~m}^{2}$. The total area of the building is 9,711.97 $\mathrm{m}^{2}$ (the City of Split Archives) according to the building permit. The three floors of the building, alighted by side openings as well as zenithal openings, represent a doubleranged standard office building (Figs. 7 and 8), organised and horizontally connected by galleries around the inner atrium, with vertical communication via freely suspended staircases in the inner atrium and via elevators in transparent envelope structures of steel and glass. The basement floor contains facilities: a restaurant and coffee bar, and server rooms, etc. In his interpretation, Plejic relates the building to several prominent administrative buildings in Split (Plejic, 1990: 12). ${ }^{6}$

The structural assembly of the Brodomerkur building is a simple system of reinforced concrete columns and beams (Figs. 8 and 9; DC Archive). The columns are laid out in a floor plan in a longitudinal direction at the axial distance of 6 meters $(5.6 \mathrm{~m}$ of the light distance between columns which are $40 \mathrm{~cm}$ wide). The axial distance in transversal direction is different; the fields along the façades have columns at a distance of 5 meters, and the central field has columns at a distance of 7 meters. The three reinforced concrete cores

building of the Banovina Palace (competition: Turina and Boltar, 1936-37; realisation: Turina, Despot and Vrbanic, 1938-40), and "according to the way how the building belongs to its environment, respects and enriches the defined context and partly according to the design register (selected materials and their interpretation)", he claims that the building is "a continuation of the direct line started by Šegvic's Office Building on the West Coast".

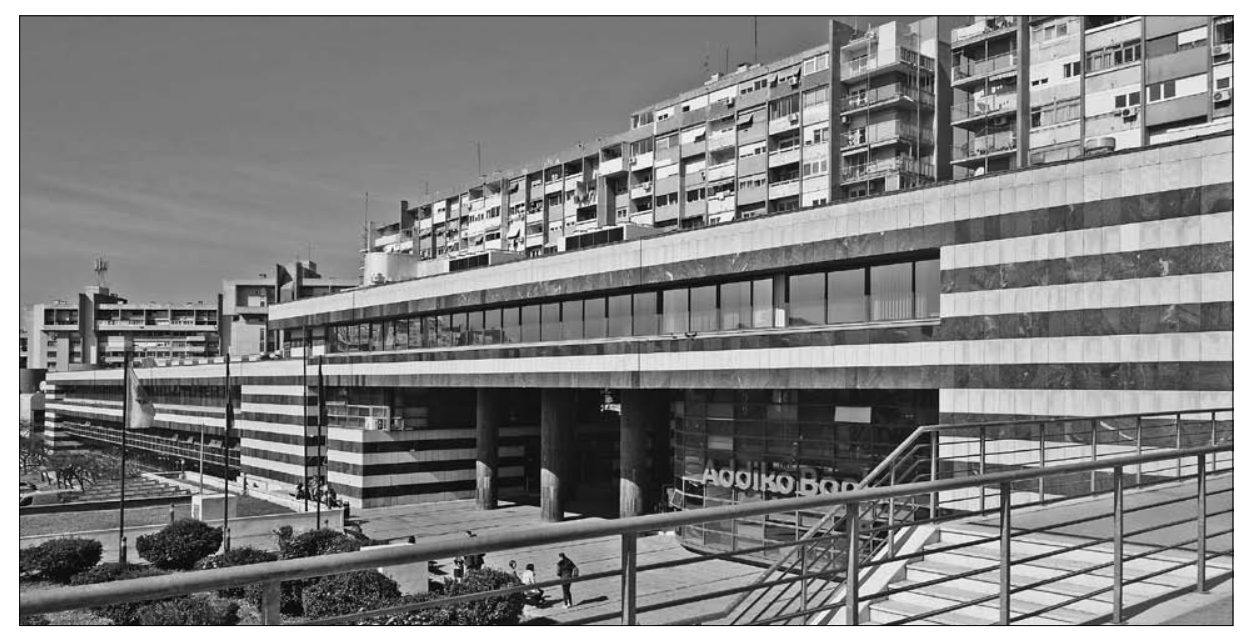

(toilets and staircases) serve as a seismic reinforcement of the entire structure of the building.

FIG. 5 VIEW OF THE SOUTHERN FAÇADE OF THE BRODOMERKUR OFFICE BUILDING, AUTHOR DANKo COLNAGO

\section{EVALUATION OF THE ARCHITECTURAL FEATURES}

The Brodomerkur building did not receive any recognition in the form of professional awards. It was included in the competition for the Croatian annual Award Viktor Kovačic at the Zagreb Salon in 1990, at which the authors Đivo Dražic and Edvin Šmit were cited for the office building for the Customs Administration and Intereuropa - Koper located at the Zagreb Fair (Oštric, 1991: 8-11). The building was also presented at the Piran Days of Architecture the same year, where it received critical praise.

According to his own words (Colnago, 2014), as an inspiration during the designing process the author used the works of Japanese architect Tadao Ando (1941), the British architect Norman Foster (1935), and in particular, the glazed façade of the Willis Faber and Dumas Headquarters in Ipswich (1970-1975) (Frampton, 1992: 325-329), as well as the works of Scottish architect James Stirling (1926-1992), specifically the canopy at the Neue Staatsgalerie in Stuttgart (1977-1984) (Frampton, 1992: 332-333; Jencks, 1986: 460, 466; Jencks, 2007: 137).

However, the whole project and various details of the Brodomerkur building are rich with references to the history of architecture, a few of which are analysed in this section. Also present are references to the work of other postmodern architects who were the author's contemporaries and active designers in the 1980s: Mario Botta (1943); Aldo Rossi (1931-1997), Robert Arthur Morton Stern (1939), and Thomas Beeby (1941).

The Brodomerkur building is perceived in the fabric of the city as a pure geometric form 


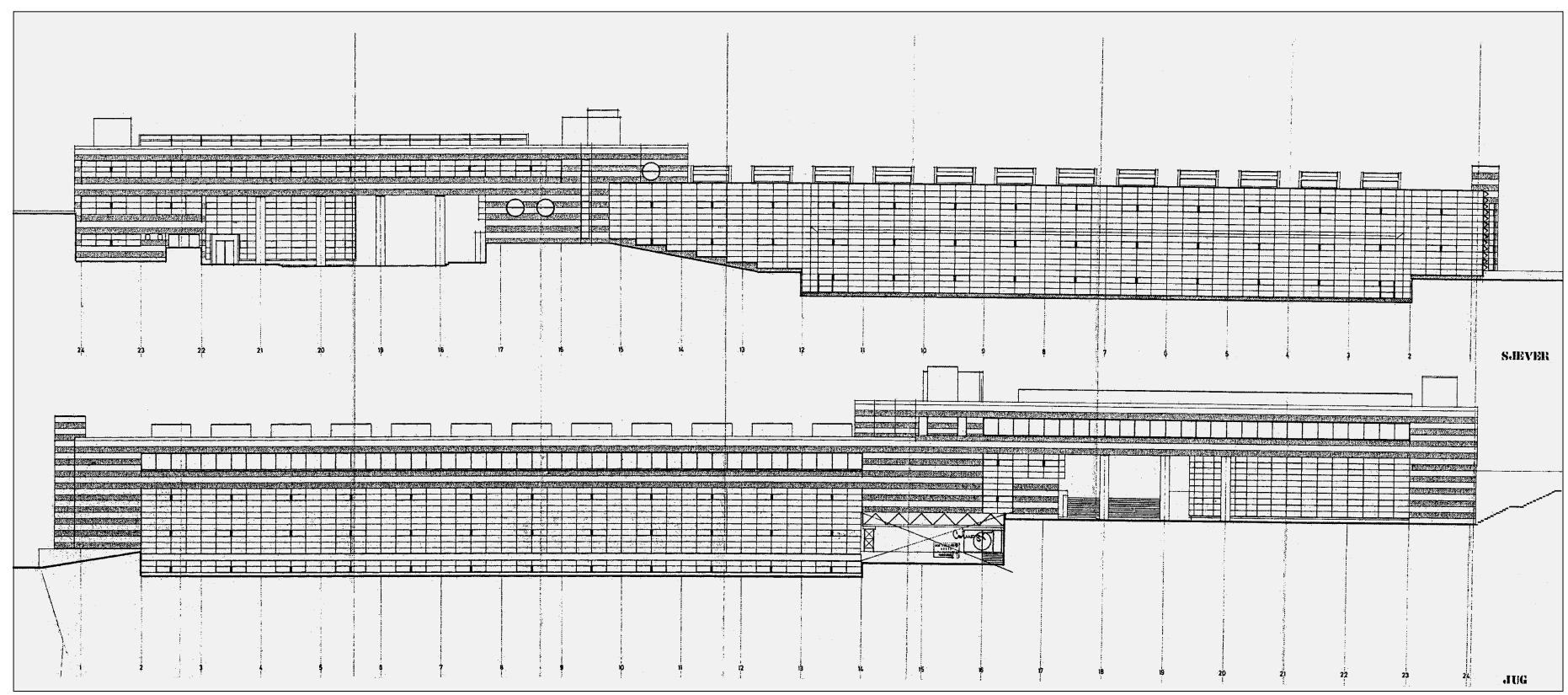

FIG. 6 NORTH AND SOUTH FAÇADES OF THE BRODOMERKUR OfFice Building, AUthor DANKo Colnago of large scale (drawing on Enlightenment architecture and Ruskin's power of size and weight). These qualities of its form, size, and weight make a visual impact that is noticeable from the speeding cars on the six-lane city road that encircles the Split peninsula (Poljička Street). ${ }^{7}$ The fundamental postmodern feature of the building as a spatial sign of the contemporary city is evident through the scale of a design that is meant to be enjoyed from a speeding car, not from the perspective of an itinerant pedestrian (Venturi, 1988: 13 , 30-35).

The tectonics of the building's solid mass, as described in the manuscripts of the Swiss architect Botta on House Bianchi (Ligornetto, 1975-1976) and House Robbiani (Massagno, 1979-1981), has the role and appearance of a "defensive wall" that accords both with the rhythm and speed of the city road, and the "idea of the form and protection" (Coppa, 2009: 23), all of which are symbols of the historical role of the wall in the Split peninsula since antiquity.

The defensive wall perforated with two openings represents a "double portal" / "colonnade"; rich in meanings, metaphors, and linguistic messages consistent with Venturi's concepts of "duality" and the "difficult whole" (Venturi, 1989: 39-44, 186-188).The visual experience of the "portal" - there is only one actual passage through the building - represents a series of historical associations, the most prominent of which is a metaphor for the city gate from one of the city's two main roads. This passage is not just an opening of the building into the surrounding urban fabric that fits into the urban matrix - in Colnago's words
- “little cardo" (Colnago, 2014), but it also marks the entrance to the building.

The graded access to the building that starts on Poljička Street (parking and/or pedestrian access/promenade lined with greenery), across the sort of "hypostyle hall" / "city loggia" and main entrance, and then through the inner atrium, is much like the one developed by Aldo Rossi on the matrix of the postmodern city and completely shaped, as a result of complex architectural education, on a project for the City Hall in Scandicci (1968; Braghieri, 1997: 38-41; Moneo, 2004: 114). At the same time, the public space of the entrance, with its columns and staircases, mirrors the urban themes integrated into Mediterranean cities such as Split (small public squares, town loggias / courts, and staircases/scalinate). This space is also what Colnago calls "an intuitive archetype" (Colnago, 2014), a product of the architect's habitus. The arrangement of elements in this public entrance space represents a postmodern sequence that creates a theatrical space, far from being a plain entrance without ambition, by which the act of entering a building is transformed into an event (Rossi, 1999: 143-144).

The postmodern pillars of the passage are lined with the longitudinally placed granite tiles resembling, in Colnago's words, the

7 The Brodomerkur Office Building establishes a relation to the highway and parking similar to the one appearing in Stern's Point West Place (Framingham, Massachusetts, 1983-1984) or Beeby's American Academy of Paediatrics (Chicago, Illinois, 1984).

8 This demonstrates the author's ambition to present the entrance like dramatic scenography. 
"vertical fluting on Doric columns" (Colnago, 2014) ${ }^{8}$; which divide the surface into wellbalanced rhythms, and each column absorbs an internal loadbearing reinforced concrete structure. The canopy of the basement service entrance below the eastern portal represents a literal quote of Stirling's canopy at the Neue Staatsgalerie in Stuttgart (Loos, 1952: 29; Ruskin, 1920: 158-159), where Constructivist's asymmetry and De Stijl's / Theo van Doesburg's triangular ornament emphasize the public entrance and protect visitors from rain (Jencks, 2007: 110).

The "bridge construction" / "double portal" of the Brodomerkur building rests on three reinforced concrete cores and a columnbeamslab system; which, according to the author, derives from the logical construction of Foster's elegant "undecorated hangar" of the Willis Faber and Dumas Headquarters in Ipswich (Frampton, 1992: 325-326, 328, 331). This construction frees the interior space by creating pure geometric shapes without load-bearing structure, liberating the façade from heavy load-bearing walls while enabling the modernist flexible organisation of the floor. Looking from the inside, the building opens to the environment through a glass "curtain wall" which represents a modernist approach. However, looking from the outside, tinted reflecting glass acts in daylight as an opaque wall with windows, which is more baroque than the modernist concept of the opening to the landscape (Giedion, 1969: 110; Zevi, 2000: 83, 85). The application of the "curtain wall" echoes the approach

of the architect Botta and the Ticino school, where the theme is sculpture expressed through emphasizing "the depth and thickness of the curtain wall" as a model for creating light, where the goal is to turn "a static technical element into a spatial entity" (Coppa, 2009: 22). Simultaneously, the use of solid, massive walls as the dominant design is in stark contrast to the glass and transparency of the façade (Ruskin, 1920: 95, 97, 100, 102), which is another example of the postmodern paradox. The formative logic of the gradation of the suspended façade towards Poljička Street can also be linked to earlier examples: Mies's expressionist vertically broken glass façade of a 1921 skyscraper at Friedrichstrasse in Berlin (Frampton, 1992: 176) and the cascading façade of the Biblioteca Civica Luigi Einaudi by Bruno Zevi and Studio A/Z (1962-1963) in Dogliana (Olivero, 2014: 1).

The façade's design demonstrates the modernist application of glazed elements rooted in industrial design, but, through cascades and roundness of the "curtain wall", it also achieves the postmodern sculptural individuality. This effort reflects the influence of Ital-

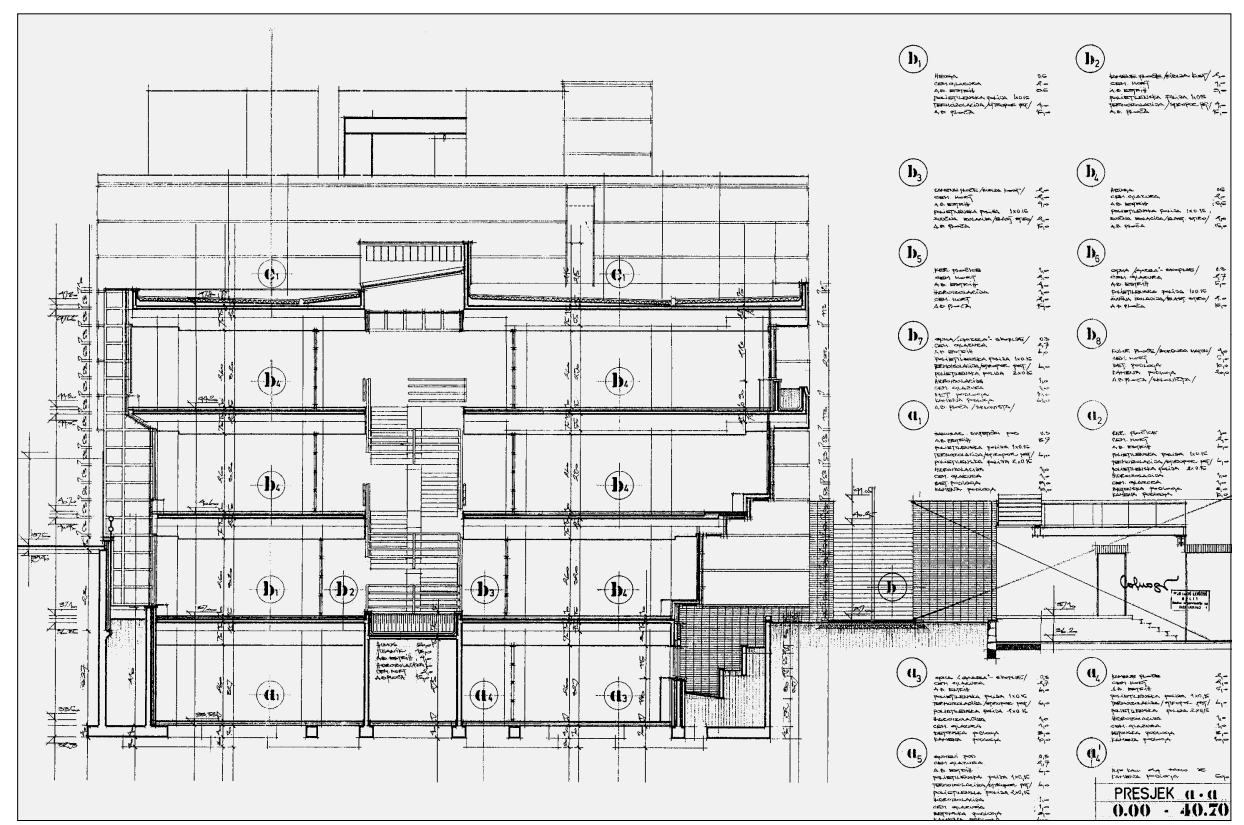

ian architects annoyed by glass envelopes encompassing the entire office buildings of

Fig. 7 Cross-section A-A through Brodomerkur Office American and British productivists which, "until yesterday", were indicative of the "evolution of the building method and architecture resulting from the industrial economy", and, in the long run, restricted architects to interior design - from Paxton and the Cristal Palace to the present day (Santi, 2007: 26-27).

The parallelepiped structure of the Brodomerkur building set on a rectangular floor plan does not show an intention to merge with the landscape, but rather to oppose it as an artificial element with prominent horizontal strips of cladding in contrast to the surrounding natural and built environment. The illusion of a "heavy stone mass" ("masks" of stone slabs) realises Venturi's "double unity" of a building that is simultaneously traditional and modernist (Venturi, 1989: 40, 43). The alternating application of black and white strips, $60 \mathrm{~cm}$ high, on the façade, has its historical basis in the area of Split and seemingly has a justified appearance. There are two nexuses worth mentioning: the nexus to the application of ancient masonry, and the nexus to the choice of black and white colour (stone cladding slabs measuring $60 \times 40 \mathrm{~cm}$ ). Examples of antique masonry, known in Dalmatia and Split, from the opus isodomum through the opus quadratum to the opus mixtum (Vitruvious, 1990: 41-43), indicate vernacular / Rossi's recognition of loci (Rossi, 1999: 139, 143, 145) in the harmony of a regular stone formation.

The choice of the black and white façade cladding stems not only from the antique BUILDing, AUthor DANKo COLNAGO 


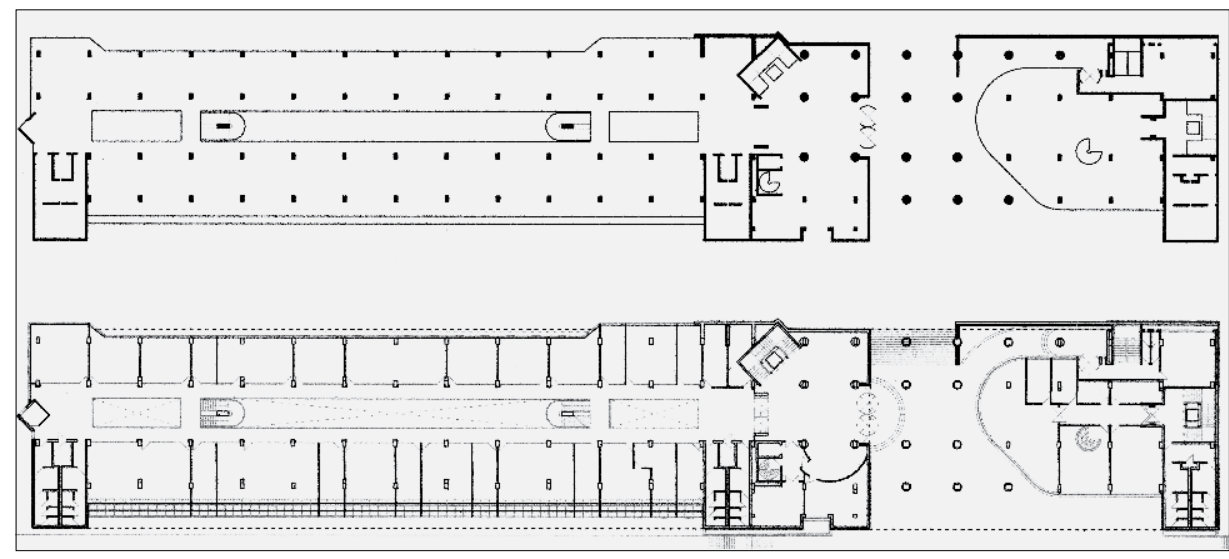

Fig. 8 GROUND FLOOR 2 OF THE BROdomerKur OfFICE BUILDING, AUTHOR DANKO COLNAGO

(Suic, 2003: 177-183; Kleiner, 2009; Lavan, 2018) ${ }^{9}$, but also from the Tuscan medieval architectural tradition (Belloni, 2000: 14-17; Donati, 1999: 11-23, Guerra, 1993: 15-33; Janson, 303- 304; Paine, 2012: 6-8) ${ }^{10}$ and modernity (Loos, 1952: 90). ${ }^{11}$ This choice makes the spectator experience the difference through the perception of dark and light (Ruskin, 1920: $87-89,95)$ and is the only possible choice in the effort to achieve the building's own strong identity in the background of the multi-coloured street through Smrdečac (formerly Mirko Kovačevic Lala Street) by architect Frano Gotovac. Colnago cites Ruskin's monochrome design as shaping the interspace between painting and engraving (Ruskin, 1920: 148).

A two-tone stone cladding that underscores the tradition of a stone syllable in rows is ubiquitous in 1980 s postmodern architecture that invokes historical styles: Botta uses it at the Watari Museum of Contemporary Art in Tokyo (1985-1990) and the Mediatheque in Villeurbanne, France (1984-1988; Jencks: 2007: 146) ${ }^{12}$, Stirling and Wilford use it at the Neue Staatsgalerie quoting Wilhelma (Middleton, 1980: 237-238, 244, 246, 248; Toman, 2006: 164, 185, 191) ${ }^{13}$, and American examples of its use appear at the Point West Place and the Academy of Paediatrics (Beeby, 1985: 78-81; Stern, 1985: 38-43).

Opposing the serious restraint and power of pure geometric volume with the two-tone stone-clad surfaces and the cascading drag or indentation of a curtain wall curve establishes a modernist modulor - a human scale in relation to the building - which, paradoxically, creates luxurious dignity which underlines the purpose of the building and expresses the image of the company mirroring its success and wealth.

The double-ranged Brodomerkur office building has the ground-floor plan divided into three fields which unfold in cross-section. This is the nexus with the architecture of the
Roman public basilica, one of the early forms of administration and trade building, but with the central nave illuminated through multiple square zenithal openings in the roof slab resembling a clerestory (Figs. 4, 7 and 8). The dynamism of the entrance hall with a reception area and the elevator is achieved through the integration of Rossi-like volumes of the two cylinders of a revolving entrance door (Braghieri, 1997: 26-27, 42-43, 162-167, 176, $179,182)$, which introduce the interior office space - a Foster-like modernist construction composed of columns and slabs, where distribution and partitioning are freely permitted as required. But, unlike Foster and again influenced by Italian neighbours, Colnago did not design the banal Bürolandshaft. Instead, he employed the use of spacious large offices to accommodate one or four people; where a common network of utilities (electricity, water, lighting, heating, ventilation) leaves the possibility of easy remodelling, thanks to raised floors and suspended ceilings. ${ }^{14}$

The design details of the offices and interior of the building are linked to Scandinavian design, deep-seated in Croatia since the 1960 s and introduced through the work of architect Bernardo Bernardi (1921-1985). The cladding panels of interior walls and partitions, and the interior carpentry, aa well as the furniture made of light ash, are in contrast to the Parisian blue colour of the floor carpets (Aalto's Savoy restaurant in Helsinki, 1937). Executive offices differ only in furniture, which is mahogany, underscoring the hierarchy by the quality of material used.

The location of sanitary facilities and staircases with a glazed steel structure of elevators within reinforced concrete cores of the "portal pillars" further punctuates the design and expression of the building's structure and Kahn's principle of the "served and servant space". The clean minimalism of the floor plan stands in postmodern counterpoint to the installation of a Foster-like "pool with goldfish" on the ground floor and "jerulas" for plants, which are absent today.

9 According to Suic, by carving all sides of the stone block with paying special attention to joints in the $1^{\text {st }}$ century $A D$, the wall canvas in Dalmatia got a prominent plas tic (two plans: a recessed plan of the joints and a protrud ing plan of the carved stone) which give the spectator a difference in perceiving dark and light ("chiaroscuro"). According to Kleiner and Lavan, the marble revetment and pure geometrical opus sectile are continuous from $2^{\text {nd }}$ to $4^{\text {th }}$ century AD in Imperium Romanum.

10 Examples of a two stone cladding in medieval Tuscan (Italian) Romanesque Architecture include the Pisa Cathedral (1063) and the Pisa Baptistery of St. John (1153), the Florence Baptistery of St. John ( $11^{\text {th }}$ century), and the lower portion of the façade of the Siena Cathedral (1284).

11 Adolf Loos also applied two-tone strips to the unrealised project of Josephine Baker's House in Paris in 1928. 12 The two-tone strips of stone cladding in Botta's works are interpreted differently: according to Joseph Rykwert 


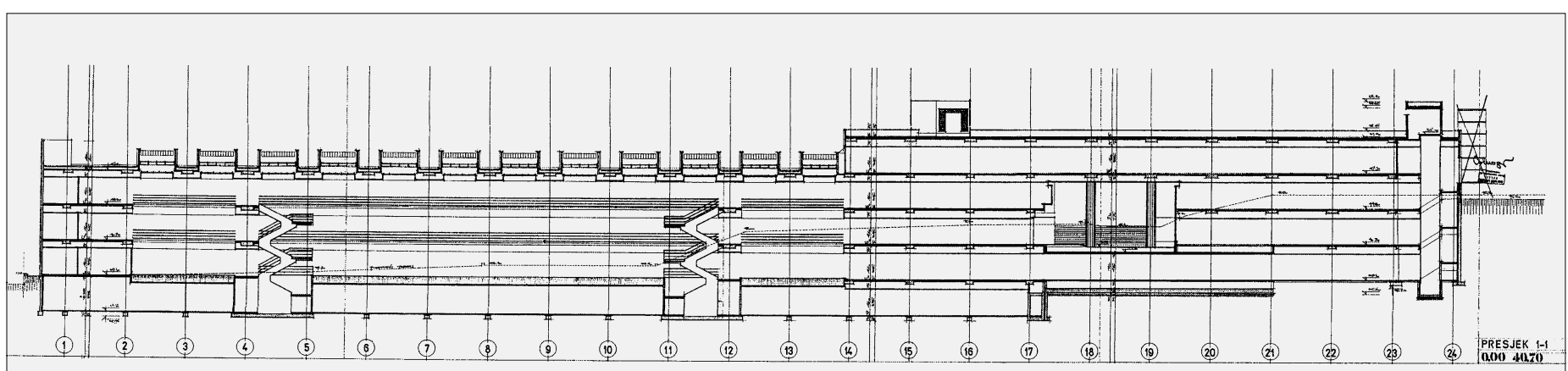

\section{DISCUSSION AND CONCLUSION}

The Brodomerkur building is a "landmark" of political, economic, and social change in the City of Split in the 1980s. Designed and built in the socialist era with a postmodern appearance that resembles luxurious buildings of capitalist corporations, the building is simultaneously a postmodern paradox; it anticipates a new historical era and is a practical example of the transformation from socialist social ownership to the capitalist private property.

In the 1980s, before the digital era, professional journals were widely available to architects in the City of Split: Domus and Abitare; L'Architecture d'Aujourd'Hui, Progressive Architecture, Architectural Record, and A.D. This enabled architects to be fully involved in urban and architectural movements of the time despite the isolation caused by the socalled "Iron Curtain". Study trips to Berlin and/or weekends in Italy were also a common practice. Architect Colnago recognized the forces of his time and achieved their resonance in his creative opus. Speaking clearly and unambiguously about architectural role models (Ando, Foster, Stirling), he inquired about other people's recognition of the context. He posed the question of how to reinterpret the general scheme in his environment, with vernacular expression, simultaneously respecting the heritage.

they are "a link to the medieval Italian tradition", according to Charles Jencks they are "an abstract form of ancient rustication", and according to Kenneth Frampton they are " $a$ continuation of the traditional construction of the $19^{\text {th }}$ century" in Ticino.

13 The two-tone strips of the façade were common in the $19^{\text {th }}$ century in the works of German and French architects: Friedrich Wilhelm von Zahnt at Wilhelma in Stuttgart (1837), Ludwig Persius at the Church of the Most Holy Redemption in Potsdam (1841) and the Pumping Station (1841-1843), Leon Vaudoyer at the Cathedral of Marseille $(1845,1852-1893)$, and Gabriel Jean Antoine Davioud at the Fountain of St. Michael in Paris (1858-1860).

14 The recent renovation of the building for a new function replaced inner glass walls between offices with gyp sum walls, causing a loss of visibility through the build ing's western "portal".
Colnago critically studied Foster's glazed hangar as a model for an office building. While reflecting on an irregular total volume squeezed between traffic flows, he responded with a parallelepiped of the limes parallel to the antique limitatio, simultaneously reading his context. Thinking of Foster's modernist glass envelope in the context of the location, Colnago responded by protecting the glass envelope from the strong Mediterranean sun by gradual indentation.

In the same context, Colnago critically studied Ando's relationship between light and darkness through the complex rotations of communications that define the building. He responded with a double ranged office building, a transposed floor plan of the three-nave Roman civil basilica, where the communication system of galleries and multiple-style staircases are illuminated by lateral and zenithal light.

Here, we can talk about apprenticeship at an international level, immersion in one's habitus, and, as a result, the creation of new work. One can discuss how much of it came from the conscious and how much from the subconscious accumulation of images and experiences of space.

For example, the two-tone cladding of the "portals" would be a superficial populist scenography typical for postmodernism (a sailor shirt for a marine equipment store), if Colnago (like Botta in Ticino) had not grown up in the area with seventeen centuries of excellence in stone masonry - from antiquity until today. The entire building is the result of the realisation of the urban and architectural values of Colnago's environment. It is a kind of a materialized essay of the local dialect of his architectural manuscript.

The Brodomerkur building has lasting Vitruvian values: utilitas through a clear division of served and servant spaces; firmitas in the stability and strength of geometry of tectonics and the high quality of used materials; and venustas in the horizontal calmness achieved through the thoughtful combination of the traditional and the modernist.
FIG. 9 LONGITUDINAL SECTION 1-1 THROUGH THE BRODOMERKUR OFFICE BUILDING, AUthor DANKo COLNAGO 
Classical canons contribute to the rooting of the building, both in the foundations of architecture (pillar and beam of the portal structure that solve the problem of light penetration and weight control) and in the city's context through the reflection and celebration of materials (limitatio of Split ager and Roman opus mixtum).

The building is a complex postmodern achievement created in the period of the architect's style confirmation. It evokes Rossi's return of the "city palace" / "building as a city". The created architecture is both historical and new. It abounds in postmodern syntax ("the place of concentrated quotations and references"). In Venturi's terms, it is ambiguous. The abstract decomposition into horizontal planes and the repetition of twotone postmodern ornament create a more pleasing background than the original strength of the modernist, engineering approach to the pregnant form of the bridge of the façade, supported by industrially designed glazed elements. The freedom to combine materials and approaches contributes to the experience of harmony, beauty, geometry, and spirit, emphasizing the postmodern mastery of Danko Colnago.

[Translated by Dina Ožic Bašic; proofread by Andrew Stambuk, Ph.D., and Boris Škvorc, Ph.D.]

\section{BIBLIOGRAPHY AND SOURCES}

\section{BOOKS}

1. Belloni, S. (2000) Siena. Florence: Casa Editrice Perseus.

2. Braghieri, G. (1997) Aldo Rossi. $3^{\text {rd }}$ ed. Barcelona: Editorial Gustavo Gilli.

3. Coppa, A. (2009) Mario Botta. Milan: II Sole 24 ORE Business Media Srl.

4. Donati, R. (1999) Pisa - Art and History. Narni: Casa Editrice Plurigraf.

5. Frampton, K. (1992) Moderna arhitektura - Kritička povijest. Zagreb: Globus.

6. GIEDION, S. (1969) Prostor, vreme, arhitektura. Beograd: Građevinska knjiga.

7. Guerra, C. (1993) Florence. All the Art Treasures of the City. Florence: Bonechi.

8. Janson, H.W. and Janson, A.F. (2003) Povijest umjetnosti. Varaždin: Stanek.

9. JENCKS, C. (1986) Moderni pokreti u arhitekturi. Beograd: IRO Građevinska knjiga.

10. JENCKS, C. (2007) Nova paradigma u arhitekturi. Beograd: Orion Art.

11. Loos, A. (1952) Ornament i zlocin. Zagreb: Mladost.

12. LYNCH, K. (1960) The Image of the City. Cambridge: The MIT Press.

13. Middleton, R. and Watkin, D. (2003) Architecture of the Nineteenth century. $2^{\text {nd }}$ ed. Milano: Electa Architecture.

14. Moneo, R. (2004) Theoretical Anxiety and Design Strategies, Barcelona: ACTAR.

15. Santi Gualteri, F. (2007) A trip through Italian design. Mantova: Edizioni Corraini.

16. SuIC, M. (2003) Antički grad na istočnoj obali Jadrana. Zagreb: Golden marketing.

17. Toman, R. (2006) Neoclassicism and Romanticism; Architecture, Sculpture, Painting, Drawings (1750-1848). Potsdam: Ullman \& Könemann, Tandem Verlag GmbH.

18. TuŠEK, D. (1996) Arhitektonski natječaji u Splitu 1945.-1995. Split: Građevinski fakultet and Drustvo arhitekata Splita.

19. Venturi, R., Izenour, S. and Scott Brown, D. (1988) Pouke Las Vegasa: zaboravljeni simbolizam arhitektonske forme. Beograd: IRO Građevinska knjiga.

20. VenturI, R. (1989) Složenosti i protivrečnosti u arhitekturi. Beograd: IRO Građevinska knjiga.

21. Vitruvious Pollio, M. (1990) Deset knjiga o arhitekturi (De architectura libri decem). Sarajevo: Svjetlost.

22. ZeVI, B. (2000) Znati gledati arhitekturu. Zagreb: Naklada Lukom.

E-BOOKS

1. RUSKIN, J. (1920?) The seven lamps of architecture. $3^{\text {rd }}$ ed. London: Waverley Book Co. Archive. org [online]. Available at: https://ia802307. us.archive.org/27/items/1920sevenlampsofoo ruskuoft/1920sevenlampsofooruskuoft_bw.pdf [Accessed: May 18, 2015] 
2. Lavan, L. (2018) Chronology in Late Antiquity: a Lesson from the Palaestra. Rome: Publications de l'École française de Rome. Books.openedition.org [online]. Available at: https://books. openedition.org/efr/3814 [Accessed: May 21, 2021], https://doi.org/10.400o/books.efr.3814

JOURNAL ARTICLES

1. Beeby, T. (1985) "American Academy of Pediatrics", Architectural Design Profile, 55 (1/2): 78-81

2. Kuкоč, V. (2010) "Razvoj Splita III od 1968. do 2009. godine", Prostor, 18 (1/39/): 166-177

3. Ośtrić, I. (1991) "Poslijepodne jednog arhomana : poslovna zgrada na Zagrebačkom velesajmu", Covjek i prostor, 1-2 (454-455): 8-11

4. PLEJIC, R. (1990) „O kreativnom u geometriji jos jednom", Covjek i prostor, 7-8 (448-449): 10-12

5. Stern, R. (1985) "Point West Place", Architectural Design Profile, 55 (1/2): 38-43

WEB SITES

1. Olivero, D. (2014) Biblioteca Einaudi a Dogliani [Online]. Available at: https://cuneofotografie. blogspot.com/2014/05/biblioteca-einaudidogliani.html [Accessed: May 18, 2015]

2. Paine, A. (2012) Botta's Striped Historicism: Historicism, Myth and Fabulation in Mario Botta's Stripes [Online]. Available at: http://www. architetturadelmoderno.it/scheda_nodo.php? id=445\&lang=_eng [Accessed: May 18, 2015]

3. SuIc, M. (1956) Ostaci limitacije naših primorskih gradova u ranom srednjem vijeku [Online]. Available at: https://hrcak.srce.hr/100592 [Accessed: May 18, 2015]

\section{ARCHIVE MATERIALS}

1. Kalogjera, B.; LuŠić, N.; Marasović, Dż; KozMAR, T.; TedesChI, S.; ŠIMUNOVIĆ, I.; Bulić, A.; BJELAJAC, S.; MAROJEVIĆ, M.; MARUŠIĆ, J.; MARASovic, T. (1977) Generalni urbanisticki plan Splita, 3. knjiga - prijedlog plana [book] Dina Ożić Bašić Archive. Split.

2. *** (1986) Uvjeti uređenja prostora br. 512-1-86/ $A U / D B$. [document] Danko Colnago Archive. Split.

3. ${ }^{\star \star \star}$ (1989) Građevinska dozvola, broj: o8/UP-/6835/88-KS-NL. [document] City of Split, City Office, Department for Legal Normative Affairs and Office and Archives Affairs. Split. (Grad Split, Ured Grada, Odsjek za pravno normativne poslove i poslove pisarnice i psimohrane. Split.)

4. *** (1989) Izmjena gradevinske dozvole, klasa: UP-I-361-03-89-01-153; ur. broj: 2181-08-05-0389-02-KS. [document] City of Split, City Office, Department for Legal Normative Affairs and Office and Archives Affairs. Split. (Grad Split, Ured Grada, Odsjek za pravno normativne poslove i poslove pisarnice i psimohrane. Split.)

5. *** (1990) Dopuna gradevinske dozvole, klasa: UP-I-361-03-90-01-66; ur. broj: 2181-08-05-0390-02-KS/DB. [document] City of Split, City Office, Department for Legal Normative Affairs and Office and Archives Affairs. Split. (Grad Split, Ured Grada, Odsjek za pravno normativne poslove i poslove pisarnice i psimohrane. Split.)

\section{AUTHOR'S BIOGRAPHY AND CONTRIBUTION}

\section{ONLINE VIDEOS}

1. Kleiner, D. (2009a) Open Yale Course Number HSAR 252 - Roman Architecture. Lecture 9 From Brick to Marble: Augustus Assembles Rome. Chapter 3. The Ascent of Augustus and Access to Italian Marble. Chapter 4. Augustus Assembles His Marble City. [video] Available at: https://oyc.yale.edu/history-art/hsar-252/lecture-9 [Accessed February 26, 2015].

2. Kleiner, D. (2009b) Open Yale Course Number HSAR 252 - Roman Architecture. Lecture 15 Rome and a Villa Hadrian's Pantheon and Tivoli Retreat. Chapter 5. Hadrian's Villa at Tivoli: Travelogue and Retreat [video] Available at: https://oyc.yale.edu/history-art/hsar-252/lecture-15 [Accessed March 16, 2015].

3. Kleiner, D. (2009c) Open Yale Course Number HSAR 252 - Roman Architecture. Lecture 16 The Roman Way of Life and Death at Ostia, the Port of Rome. Chapter 7. Re-emergence of the Domus at Ostia and Tombs at Isola Sacra. Title: Domus of Fortuna Annonaria. [video] Available at: https://oyc.yale.edu/history-art/hsar-252/ lecture-16 [Accessed March 26, 2015].

\section{INTERVIEWS}

1. Ožić Bašić, D., Colnago, D. (2009) Initial contact with the author.

2. Ožic Bašić, D., Colnago, D. (2014) Interview with the author.

\section{ILLUSTRATION SOURCES}

FIG. 1 Kaminski, B. (1986?) Perspective drawing. Danko Colnago Archive. Photo: Dina Ožić Bašić (jpg file, $350 \mathrm{dpi})$

FIG. 2 Kaminski, B. (1989) Perspective drawing. Danko Colnago Archive. Photo: Dina Ožic Bašić (jpg file, $350 \mathrm{dpi}$ )

FIg. 3 Kalogjera, et al., 1977. Dina Ožić Bašic Archive, Split (jpg file, $350 \mathrm{dpi})$

FIG. 4 Colnago, D. (1988) Detailed design. Commercial \& Business Centre Brodomerkur. Sheet 2. Danko Colnago Archive (tiff file, $400 \mathrm{dpi})$

Fıg. 5 Photo: Dina Ožic Bašić (jpg file, 350 dpi)

FIG. 6 Colnago, D. (1988) Detailed design. Commercial \& Business Centre Brodomerkur. Sheet 6. Danko Colnago Archive (jpg file, 600 dpi)

FIG. 7 Colnago, D. (1988) Detailed design. Commercial \& Business Centre Brodomerkur. Sheet 3. Danko Colnago Archive (jpg file, 600 dpi)

FIG. 8 Colnago, D. (1988) Detailed design. Commercial \& Business Centre Brodomerkur. Sheet 1.5. Danko Colnago Archive. Auto CAD Drawing after Danko Colnago Archive: Dina Ožic Bašic (jpg file, $1200 \mathrm{dpi)}$

FIG. 9 Colnago, D. (1988) Detailed design. Commercial \& Business Centre Brodomerkur. Sheet 5. Danko Colnago Archive (jpg file, 600 dpi)
Associate professor DINA OžıĆ BAŠıć, Ph.D., graduated in 1994, got a Master of Science degree in 2003 and Doctorate in 2006 at the Faculty of Architecture, University of Zagreb. Her early research was on public religious and cultural buildings. Her present research is about postmodern architecture and the architectural heritage of the $20^{\text {th }}$ century, in particular postmodern urbanism and postmodern architecture in the 80 and 90 s city of Split.

The author prepared the whole work. 


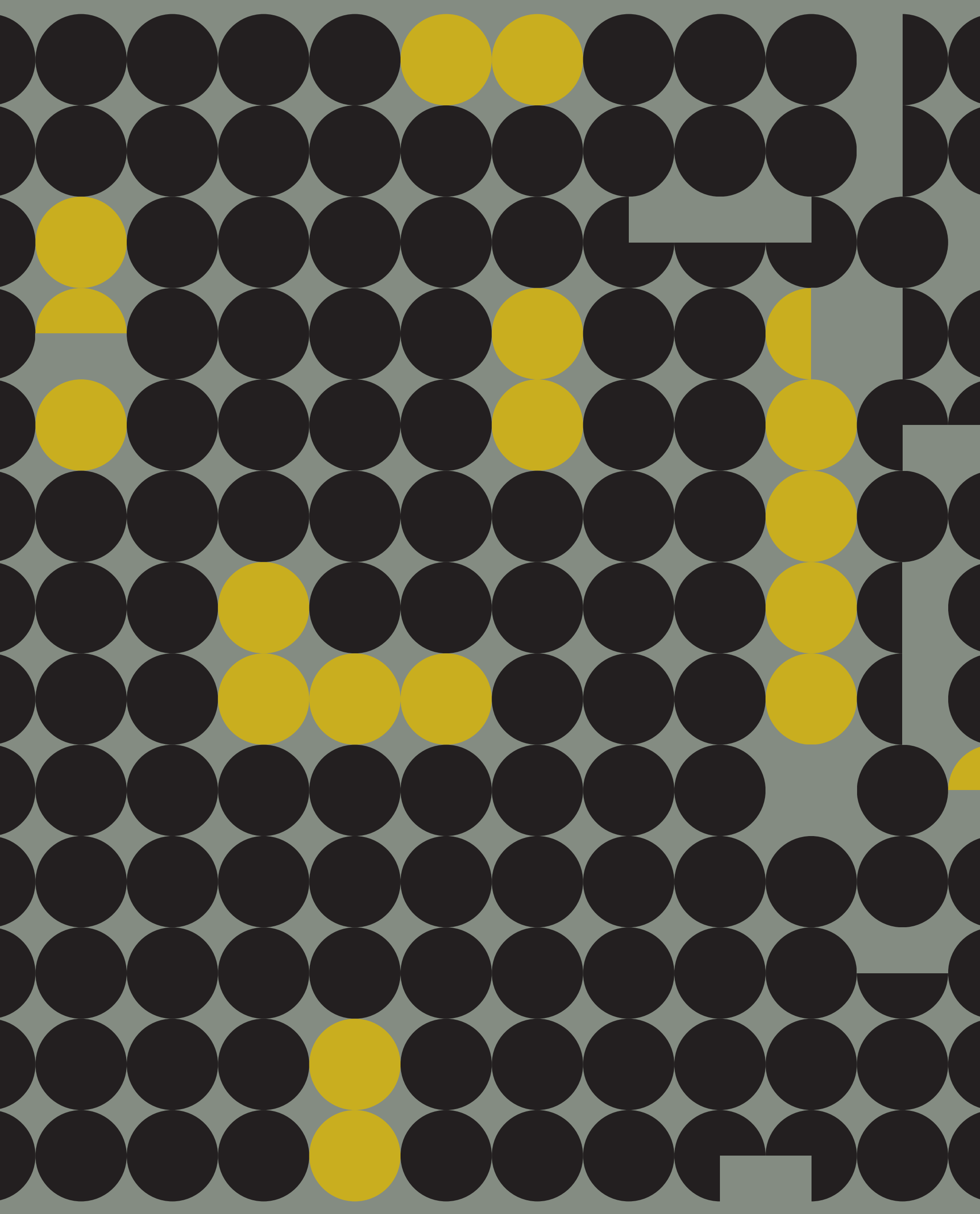

